\title{
The Effect of Contextual Teaching and Learning Model and Motivation towards Skill of Fable Text Writing
}

\author{
Nur Kurnia Setiawati, Syahrul Ramadhan, Erizal Gani \\ Universitas Negeri Padang \\ Nurkurniasetiawati30@gmail.com
}

\begin{abstract}
This study aimed to describe fable text writing-skills of students taught by the learning model contextual teaching and leraning and conventional learning models, describing the skills to write text fable students taught through learning model contextual teaching and leraning motivated high learning, and students are taught using learning model of direct instruction motivated high learning in students class VII SMPN 25 Padang. This research was quantitative with a $2 x 2$ factorial experimental design. The study population was the seventh grade students of SMPN 25 Padang. Data were collected through questionnaires and skills tests fable writing text. Based on the research that learning model contextual teaching and leraning affect text fable writing skills. Fable text writing skills students taught with contextual teaching and learning models are highly motivated leraning better than text fable writing skills students taught by conventional learning models that are highly motivated. There is no interaction between model contextual teaching and leraning and motivation to learn in text fable affects writing skills.
\end{abstract}

Keywords--influence, contextual teaching and leraning, conventional, motivation to learn, fable

\section{INTRODUCTION}

Indonesian language learning in the curriculum in 2013 requires students to have an attitude, knowledge and skills are balanced. Skills writing is one aspect that must be mastered the language skills of students, in addition to three other skills ie listening, speaking, and reading (Suhaimi, 2016). Through writing, one is able to share ideas, information, feelings, persuade, and convince others. many factors difficulty in writing not only of the student, such as characters, cognitive development and motivation, but also from the students, such as how students acquire the learning writing (Suhaimi, 2016; Syahraini, 2014; Mohamed, 2015).

One of the writing skills learned in 2013 at the School Curriculum (SMP) Class VII, the text writing skills fable. It is listed in Core Competence ((KI) 3 and Competency (KD) 3.12. Core Competence (KI) 3 that understands knowledge (factual, conceptual and procedural) based on curiosity about science, technology, arts, culture-related the visible phenomena and events. Competency (KD) 3:12 it examines the structure and language fable / legend of the local area is read and heard (Harsiati 2016, p. 105).

Text this fable is one kind of narrative text with figures of animals that have properties such as the people in it, students should be able to understand well how the text structure fable and how to compose the text fable that has a charge of moral value in it (Mislaini, 2015; Kayhan and Mohammadzadeh, 2017; Abrar, 2016). Fable often called a moral story because the message in the story is closely related to moral fable. Fable teaches readers noble in attitude and actions (Aprima, 2018; Fitma, 2017; Yunita, 2017; Utami, 2017; Rahmawati, Roekhan, Nurchasanah, 2016). Therefore, students should be able to memulis text because through writing texts fable fable students develop critical and creative thinking skills.

Based on interviews conducted with one of the Indonesian teachers who teach in class VII SMPN 25 Padang named Maswenti on August 10, 2017, obtained information that the students' ability to write text fable still low. It is seen in the value of written exercises students who do not meet the minimum completeness criteria (KKM), which is under 75. In general, students are still difficult to compose a sentence in the text. Various factors that affect it. First, the difficulty of students expressing ideas in writing the text of the fable. Second, the lack of students' understanding of the structure and characteristics of the text language fable. Third, students are poorly trained in writing the text of the fable. This is because students only write when the teacher gives the task. Fourth, the lack of student motivation, especially in writing the text fable. It makes no attempt to deepen students' writing skills. Fifth, students tend to get bored in the study of texts fable that students do not mean it in the study.

One of the ways to solve the problems of writing this poem text is to use a learning model contextual teaching and learning. CTL model serves as a communication forum for sharing experiences and ideas. Students are placed as a subject of study that has characteristics, learning styles and interests of the various things which if explored its potential can develop creative and innovative (Suprianto, Ida and Herman, 2016). Furthermore, CTL essence helps teachers to relate the subject matter to real life and motivate students to relate the knowledge they have acquired with their lives. The learning model CTL is a concept that is supported by a wide range of actual research in cognitive science 
(cognitive science) and theories about the behavior (behavior theories) equivalent (Chusni, Mahardika, Sayekti, Setya, 2017; Sanusi, 2016; Ning, 2016; Ampa, Basri, Andriani, 2013; Diyanto, 2013; Satriani, 2012).

Trianto (2009), argued that "contextual learning (Contextual Teaching and Learning) is a concept of learning that helps teachers link between the material taught with real-world situations students and encourage students to make connections between the knowledge possessed by its application in lif-pan them everyday, involving seven major components of effective teaching, namely: constructivism, questioning, inquiry, community learning, modeling and authentic assessment.

Based on the description, the following research objectives. First, describe the text fable writing skills students are taught using learning model contextual teaching and learning, with students taught using conventional models in class VII SMPN 25 Padang. Second, the text describes fable writing skills of students have high motivation to learn dibelajarkan using learning model contextual teaching and learning with students who have high motivation to learn is taught using the conventional model in class VII SMPN 25 Padang. Third, describing the interaction between the learning model contextual teaching and learning and learning motivation against fable text writing skills class VII SMPN 25 Padang.

\section{METHODS}

The procedures in research data processing were performed using the figures. Figures in this study are the score and the value of learning motivation questionnaire and scores and grades of text fable writing skills test class VII SMPN 25 Padang. Thus, it can be said that this study used a quantitative approach. The method used in this study is an experimental method using a quasi-experimental type of (quasi). The purpose of this quasi experiment is to obtain information that is thought to information obtained by actual experiment in a state that does not allow to control and manipulate all relevant variables. The design was a $2 \times 2$ factorial design.

The study population all students of class VII SMPN 25 registered Padang 2017/2018 as the population in this study. Seventh grade students of SMPN 25 Padang scattered in eight classes with the number of 241 people. Sampling in this study conducted by random sampling technique. Determining the experimental class and control class at random by drawing technique. Thus obtained VII.5 grade students as an experimental class and control class VII.6 class. Based class normality and homogeneity test samples, the results are normally distributed both this class and homogeneous.

The study consists of three variables. First, the independent variable (independent variable) is a learning model contextual teaching and learning. Second, the dependent variable (the dependent variable) is a fable text writing skills. Third, the moderator variable is the motivation to learn. The data used in this study. First, score the results of learning motivation questionnaire filling. Second, the test result score fable text writing skills students by using learning model contextual teaching and learning and the conventional model. Third, the writing skills test result score fable text that uses the learning model contextual teaching and learning. fourth, writing skills test result score fable text that uses the conventional model.

The instrument used to collect the data of this study consists of two instruments, namely sheets questionnaire and test performance. Sheet questionnaire used to determine the motivation to learn while performance tests used to measure students' skills in writing texts fable. The questionnaire consists of 40 statements, after tested obtained a valid result consists of 34 statements and invalid consisting of 6 statement. Data is said to be valid if $r$ table $<r$ count. Third, after obtaining validity then determined whether the data is reliable or not. Based on research that has been done that the questionnaire is declared reliable because $\mathrm{r}$ table $<\mathrm{r} 110.349<0.704$. Fourth, the valid statement distributed to the experimental class and control class.

Test write text fable in this study is the performance. The steps in preparing the text fable writing test instruments, as follows. First, the manufacture of lattice based on indicators. Second, composing about or order in accordance with the test indicators. Third, do a rational analysis to look at the suitability of items with the aspects measured. Fourth, make an assessment rubric text fable writing skills. Fifth, make Learning Implementation Plan (RPP) and test instruments fable text writing skills. Sixth, Learning Implementation Plan (RPP) and test instruments fable text writing skills validated beforehand and consulted with professional validator, Dr. Abdurahman, M.Pd. In addition, Learning Implementation Plan (RPP), and research instruments are also validated by the Indonesian teacher at SMPN 25 Padang, namely Maswenti, M.Pd.

\section{FINDING AND DISCUSSION}

In this section will describe two things about the result of the writing skills fable text control class and experimental class, is as follows. First, fable text writing skills of students taught by the learning model contextual teaching and learning and conventional learning models. Second, fable text writing skills of students High-taught learning motivated learning model contextual teaching and learning and conventional learning models. Third, there is no interaction between learning models contextual teaching and learning and motivation to learn in text fable affects writing skills. 


\section{The Skills of Fabel Text Writing of the Students in Learning by Using Contextual Teaching and Learning Model and model of Direct Instruction}

The second hypothesis testing showed results which stated that in general, the text fable writing skills of students in the experimental class taught by the learning model contextual teaching and learning better than text writing skills of students in the control class fables taught by conventional learning models. This can be seen from the calculation of the hypothesis test, indicating $\mathrm{t}=$ and table $=1.65$ on a real level of 0.05 and $\mathrm{df} 59$. The calculation results showed that $\mathrm{H} 1$ is accepted for $\mathrm{t}>\mathrm{t}$ table: 2,72

Learning model of contextual teaching and learning can improve students' ability to write a fable that has a high learning motivation. This is because the model of contextual teaching and learning begins with a different class atmosphere so that students find a way to express their ideas and problems into a text fable. As Johnson (2007 P.43) suggests that there are eight components of contextual teaching and learning system. Eight of these components, including: (1) create linkages-linkages meaningful, (2) conducting meaningful work, (3) conduct self-regulated learning, (4) cooperate, (5) critical and creative thinking, (6) helping individuals to grow and develop, and (7) reaches a high standard and (8) using authentic assessment.

Besides, students are able to explore the knowledge sought by reading and have a strong curiosity because students will not be satisfied if he has not found what he was looking for. It can be seen from the many questions that arise during the learning takes place. Munandar (2004, p. 59) states that asking questions is part of creative thinking and is intended to measure the flexibility of thinking. In writing the text of the fable appears that many students begin to write each expression, no smile, anger, and so forth. Tests given to students is to test the performance, a test write text fable conducted in the experimental class and control class. A test given to two of the same class, there is no difference whatsoever. This test is done to see the effect of the application of contextual learning model of teaching and learning to text fable writing skills class VII SMPN 25 Padang.

The learning process in the experimental class is more active than the classroom learning process control. In the experimental class, Model CTL improve writing skills fable text for students more aware of the theories about the text fable. In addition, CTL model to encourage students to always always actively looking for the subject matter to be discussed with peers and teachers, increase the good cooperation with the aim of learning outcomes (Dea, Diah and Regina, 2016; Nur, 2013).

In the control class students are taught using a model conventional, The conventional model it in practice using one-way communication and teacher-centered. Teacher memeberikan pembejalan or deliver material directly to students' learning. Teachers are dominating the learning process, so that students become less active.

The theory is true because the learning model conventionalcan not increase the value of students' writing skills fable text. modelconventionalin each learning activity is always dominated by the teacher, while the role of students is very limited. This condition will only get worse for students who have knowledge substandard, they will more quickly get tired and tends to avoid ongoing learning.

Based on these descriptions, it can be concluded that the results of research and analysis of the data shows that the learning model contextual teaching and learning effect and positive impact on the skills of writing text fable. Implementation of the learning model contextual teaching and learning easier for students to understand the material and give students encouraged the students to always always actively looking for the subject matter to be discussed with peers and teachers, increase the good cooperation with the aim of learning outcomes. The results of the test performance of students taught experimental class learning model contextual teaching and learning is higher than the results of the test performance of students taught by conventional models.

\section{The Skills of Fabel Text Writing of the Students Who Have Learning Motivation High Using Contextual Teaching and Learning Models and Model Direct Instruction}

The second hypothesis testing showed results which stated that in general, the text fable writing skills highly motivated students in the experimental class taught by learning models Contextual Teaching and Learning better than text fable writing skills highly motivated students in the control class taught by learning models conventional, This can be seen from the calculation results indicating the hypothesis test $t=2,51$ dan table $=1,76$ on the real level of 0.05 and df 16. The calculation results showed that $\mathrm{H} 1$ is accepted for $\mathrm{t}>\mathrm{t}$ table.

Learning model Contextual Teaching and Learning can improve the ability to write text fable highly motivated students. This is in accordance with the principles This is because a CTL model begins with a different class atmosphere so that students find a way to express their ideas and problems into a text fable. As Johnson (2007 P.43) suggests that there are eight components of the CTL system. Eight of these components, including: (1) create linkageslinkages meaningful, (2) conducting meaningful work, (3) conduct self-regulated learning, (4) cooperate, (5) critical and creative thinking, (6) helping individuals to grow and develop, and (7) reaches a high standard and (8) using authentic assessment.

During the learning takes place, the students in the experimental class has a curiosity that is stronger, as well as the characteristics of CTL which includes: (1) collaboration, (2) mutual support, (3) fun, (4) not boring (joyfull, 
comfortable), (5) study with passion, (6) integrated learning, (7) using a variety of sources, (8) active students. It can help students learn more leverage. In addition, the presence of student motivation, the students will have the spirit to remove insights, ideas and opinions about the themes discussed and will they discuss in their small groups. In addition, students will have pembendaharaan vocabulary and sentence lot and is ready to be written into a text article fable. The results of this study are still in accordance with previous studies Budiyanti (2014) and Ma'arufah (2016) which stated that students' poor performance was also accompanied by low motivation of students in participating in the learning process. Apalabila students have high motivation to learn the results of their study will be good and vice versa.

Control class that implements the conventional learning model puts students as a learning object that acts as a passive recipient for a teacher-centered learning. Class. Learning in this study were more likely individual, theoretical and abstract, knowledge is constructed by others and are obtained through memorization and exercises (Sanjaya, 2006, p.259). Such conditions lead to students who have low learning motivation is not interested to follow the learning well. Such conditions lead to students who have low learning motivation is not interested to follow the learning well. In the conventional model students the opportunity to put the idea they have is limited, and students can play an active part because there are instructions in learning.

Based on the above, it can be concluded that the results of the test's ability to write text fable highly motivated students that learned by the learning model contextual teaching and learning better than high-motivated students learn that learned to conventional models.

\section{Interaction between Learning and Motivation Model Contextual Teaching and Learning Influencing the Skills of Fabel Text Writing}

Two-way ANOVA count results for the fourth hypothesis testing showed that there is no interaction between learning models CTL with the motivation to learn to text fable writing skills. Means that the main influence factor model of learning CTL and motivation to learn each run by independent influencing fable text writing skills. For that reason, there is no influence of the interaction model of learning CTL and categories of learning motivation towards writing skills fable text. Many other factors may be supporting the text fable writing skills, such as talent, intelligence, and others. The absence of interaction model of learning CTL and learning motivation occurs on the second level of motivation to learn, both of which have a high motivation to learn, and which has a low learning motivation. The absence of these interactions means that each factor of the learning model CTL and motivation to learn not depend on each other in affecting student writing skills fable text experimental class and control class. However, the learning model CTL more effectively applied at both levels of motivation.

\section{CONCLUSION AND RECOMMENDATION}

Based on the findings of this study concluded that the learning model Contextual teaching and learning text fable affects writing skills. The effect can be explained as follows. First, the text fable writing skills of students that learned by the learning model contextual teaching and learning better than the writing skills of students that learned fable text with conventional learning models. First, the test results fable text writing skills students use models contextual teaching and learning with an average of 77,09 is higher than the test results of students' writing skills using a conventional model with an average of 67,30 . Second, the text fable writing skills taught by highly motivated students with learning model contextual teaching and learning better than text fable writing skills students taught by conventional models. It was proven that the average value of the experimental class of highly motivated 92,86 while the average value of the control class highly motivated 88,10 . Thus, the treatment accorded by using models contextual teaching and learning has an advantage than conventional models, both overall and by considering factors of learning motivation high. Third, there is no interaction between learning models contextual teaching and learning and motivation to learn in text fable affects writing skills.

\section{References}

Abrar, M. (2016). Learning from fables: moral values in three selected english stories. Dinamika Ilmu. 16, (1).

Ampa, A., T., Basri, M. D., Andriani, A., A. (2013). The development of contextual learning materials for the english speaking skills. International Journal of Education and Research. 1, (9).

Aprima, R. (2018). Pengaruh model discovery learning terhadap keterampilan menulis teks fabel siswa kelas VII SMP negeri 16 Padang. Jurnal Pendidikan Bahasa dan Sastra Indonesia, 1 (7), p. 215-221.

Chusni, M. M., Mahardika, A., Sayekti, I. C., Setya, W. (2017). The profile of student activities in learning basic natural science concepts through the contextual teaching and learning (CTL) approach with group investigation (GI) model. Jurnal Penelitian dan Pembelajaran IPA. 3 (1), p. 1-10.

Fitma, T. (2017). Pengaruh penggunaan model problem based learning terhadap keterampilan menulis teks fabel siswa kelas VII SMP negeri 4 Payakumbuh. Jurnal Pendidikan Bahasa dan Sastra Indonesia. 6 (2), p. 368-373.

Harsiati T, Trianto A., dan Kosasih E. (2016). Bahasa indonesia kementerian pendidikan dan kebudayaan edisi revisi (buku guru). Jakarta. Politeknik Negeri Media Kreatif. 
Johnson, E. B. (2010). Contextual teaching and learning: menjadikan kegiatan belajar mengajar mengasyikkan dan bermakna. Terjemahan Ibnu Setiawan. Bandung: MLC.

Kayhan, H., \& Mohammadzadeh, B. (2017). The use of fables in science laboratory. EURASIA Journal of Mathematics Science and Technology Education. 13 (8). ISSN: 1305-8223.

Mohamed, I. (2015). University students english writing problem: diagnosis and remedy. (online) dalam International Journal of English Language Teaching. 3 (3), p. 40-52.

Satriani, I., Emilia, E., Gunawan, H, M. (2012). Contextual teaching and learning approach to teaching writing. Indonesian Journal of Applied Linguistics. 2 (1), p. 10-22.

Suhaimi. (2016). Teaching writing skill on recount text based on brainstroming in the classroom (online) Jurnal Ta'dib, 19 (1).

Suprianto, Kholida, \& Andi (2016). Pengaruh pendekatan contextual teaching and learning (CTL) berbantuan media powerpoint terhadap peningkatan hasil belajar ipa fisika. Jurnal Penelitian dan Pembelajaran IPA. 2 (2), p. 168.

Susiloningsih, W. (2016). Model pembelajaran CTL (contextual teaching and learning) dalam meningkatkan hasil belajar mahasiswa PGSD pada matakuliah konsep IPS dasar. Jurnal Pedagogia. 5, (1). ISSN 2089 -3833.

Syahraini, E. (2014). Peningkatan keterampilan menulis teks berita melalui pendekatan kontestual siswa kelas VIII H SMP negeri 4 Tambang Kabupaten Kampar. (Online) dalam jurnal Bahasa, Sastra dan Pembelajaran. 2, No 2014.

Trianto. (2009). Mendesain model pembelajaran inovatif-progresif. Jakarta: Kencana.

Utami, A. N. R. (2017). Pengaruh model pembelajaran kooperatif tipe think pair share terhadap keterampilan menulis teks cerita moral/fabel siswa kelas VIII SMP negeri 4 Solok Selatan. Jurnal Pendidikan Bahasa dan Sastra Indonesia. 6 (2), 305-311.

Yunita, F. (2017). Pengaruh model problem based learning berbantuan media gambar berseri terhadap keterampilan menulis teks fabel siswa kelas VII SMP negeri 31 Padang. Jurnal Pendidikan Bahasa dan Sastra Indonesia. 6 (2), p. 102-109. 